\title{
THE EFFECT OF ORAL ADMINISTRATION OF CALCIUM FRUC- TOSE DIPHOSPHATE ON THE SERUM ORGANIC PHOS- PHATE, INORGANIC PHOSPHATE, CALCIUM, PROTEIN, AND CITRIC ACID LEVELS ${ }^{1}$
}

\author{
By SAMUEL NATELSON,2 MARGARET KLEIN, AND BENJAMIN KRAMER \\ (From the Jewish Hospital of Brooklyn, Brooklyn, N. Y., and the Rockford Memorial \\ Hospital, Rockford, Ill.)
}

(Submitted for publication June 22, 1950; accepted, October 17, 1950)

It has been clearly demonstrated that the rate of glucose absorption is independent of the concentration of the glucose solution introduced into the intestine (1-4). This has been interpreted as indicating that glucose absorption is an enzymatic process in which phosphorylation at the wall of the intestine precedes the absorption of glucose (5-7). This mechanism has been thoroughly tested and evidence in its favor is convincing (810). It appeared to us, therefore, that hexosephosphates introduced into the intestinal tract might be absorbed directly, without splitting of the phosphate linkage with the exception of that material which would be hydrolyzed by stomach acids and destroyed by the intestinal flora. It was therefore decided to determine the manner in which a hexosephosphate given orally to adults is absorbed. The adults studied were patients taken from our wards who showed no evidence of impaired intestinal absorption.

The administration of large amounts of inorganic phosphate is not an innocuous procedure in that one runs the risk of reducing the calcium ion concentration to a low level with resultant tetany. It was therefore decided, in this preliminary study, to administer calcium simultaneously. This could conveniently be done by administering the hexosephosphate in the form of its calcium salt. Calcium fructose diphosphate is readily available and was, therefore, the substance chosen.

The calcium fructose diphosphate was prepared by the Ernst-Bischoff Company, ${ }^{3}$ in the form of a fine powder, and also in pills containing 0.5 gram of this material. If we assume that one molecule of this material contains two atoms of calcium and two phosphate groups, then

\footnotetext{
1 Presented at the Federation Meeting of the American Societies for Experimental Biology at Atlantic City, April, 1950.

2 Present address, Rockford Memorial Hospital, Rockford, Ill.
}

the empirical formula is $\mathrm{C}_{6} \mathrm{H}_{12} \mathrm{O}_{12} \mathrm{P}_{2} \mathrm{Ca}_{2}$ and the molecular weight, 418. Theoretically, 14.8 per cent phosphorus and 19.1 per cent of calcium should be present in the molecule. On analyzing the product, 13.6 per cent of phosphorus was obtained and $\mathbf{1 7 . 2}$ per cent of calcium. ${ }^{3}$

Calcium fructose diphosphate is apparently readily hydrolyzed. It was observed that preparations which had been kept in stoppered bottles, but which had been opened frequently over a nine months' period, lost a high percentage of their organic phosphate content, the phosphate in the material becoming inorganic. The material used, therefore, was tested for its inorganic phosphate content. If the material contained more than 2 per cent of its phosphate in the inorganic form, it was discarded. Calcium fructose diphosphate is more soluble than calcium phosphate, and a preliminary test may be made by shaking up $20 \mathrm{mg}$. in $25 \mathrm{ml}$. of water. The material should dissolve readily with no residue.

The criteria of whether the hexosephosphate has reached the blood stream were determined by the organic phosphate content of the serum after the proteins had been removed. Inorganic phosphate was also measured. Calcium and two substances which normally form complexes with calcium, namely, citric acid and protein, were also estimated. Calcium was done by the method of Sobel and Sobel (11). Inorganic phosphorus was done by a modified method of Fiske and Subbarow (12, p. 579). Total protein was done by a modified biuret method (13). Citric acid was done by the method of Natelson, Pincus, and Lugovoy (14). Determination of total non-protein phosphorus was done by digestion of the trichloracetic acid filtrate of cell free serum $(12$, p. 581$)$. When $50 \mu \mathrm{g}$. of phosphorus as calcium fructose diphosphate or as calcium glyceryl monophosphate were added per $\mathrm{ml}$. of serum, 94 to 102 per cent of the phosphorus added was recovered by this method.

As determined by recoveries of added amounts of various constituents to serum, citric acid was determined with an accuracy of 5 per cent, inorganic phosphorus with an accuracy of 3 per cent and calcium with an accuracy of 3 per cent. Per ml. of serum, $20 \mu \mathrm{g}$. of citric acid, $40 \mu \mathrm{g}$. of inorganic phosphorus, and $50 \mu \mathrm{g}$. of calcium were added

${ }^{3}$ Calcium fructose diphosphate is manufactured by the Ernst Bischoff Co. of Ivorytown, Conn., under the trade name of Com-B-Phos. The material supplied us contained some water of crystallization. The company makes an anhydrous product which they claim is more stable. 
TABLE I

Change in serum levels after administration of 6 grams of calcium fructose diphosphate

\begin{tabular}{|c|c|c|c|c|c|c|c|}
\hline \multirow{2}{*}{$\begin{array}{c}\text { Case* } \\
\text { no. }\end{array}$} & \multirow{2}{*}{ Time } & \multicolumn{3}{|c|}{$\begin{array}{l}\text { Non-protein phos- } \\
\text { phorus (mg. \%) }\end{array}$} & \multirow{2}{*}{$\begin{array}{l}\text { Cal- } \\
\text { cium }\end{array}$} & \multirow{2}{*}{ Citrate } & \multirow{2}{*}{ Protein } \\
\hline & & Total & $\begin{array}{l}\text { Inor- } \\
\text { ganic }\end{array}$ & Organic & & & \\
\hline 1 & $\begin{array}{c}\text { hrs. } \\
\text { Fasting } \\
1 \\
2 \\
3\end{array}$ & $\begin{array}{l}3.9 \\
5.8 \\
6.7 \\
6.1\end{array}$ & $\begin{array}{l}3.3 \\
3.2 \\
3.3 \\
3.5\end{array}$ & $\begin{array}{l}0.6 \\
2.6 \\
3.4 \\
2.6\end{array}$ & $\begin{array}{c}m g . \% \\
10.1 \\
10.3 \\
10.5 \\
10.4\end{array}$ & $\begin{array}{c}m g . \% \\
2.03 \\
1.91 \\
2.03 \\
2.00\end{array}$ & $\begin{array}{l}\% \\
7.3 \\
7.5 \\
7.3 \\
-\end{array}$ \\
\hline 2 & $\begin{array}{c}\text { Fasting } \\
1 \\
2 \\
3\end{array}$ & $\begin{array}{l}3.1 \\
5.6 \\
6.1 \\
4.7\end{array}$ & $\begin{array}{l}2.7 \\
2.9 \\
3.4 \\
3.0\end{array}$ & $\begin{array}{l}0.4 \\
2.7 \\
2.7 \\
1.7\end{array}$ & $\begin{array}{r}9.7 \\
10.3 \\
10.2 \\
10.3\end{array}$ & $\begin{array}{l}1.89 \\
2.20 \\
1.93 \\
2.03\end{array}$ & $\begin{array}{l}6.3 \\
6.4 \\
6.2 \\
6.5\end{array}$ \\
\hline 3 & $\begin{array}{c}\text { Fasting } \\
1 \\
2 \\
3\end{array}$ & $\begin{array}{l}3.4 \\
4.4 \\
5.8 \\
6.7\end{array}$ & $\begin{array}{l}3.0 \\
3.7 \\
4.1 \\
3.8\end{array}$ & $\begin{array}{l}0.4 \\
0.7 \\
1.7 \\
2.9\end{array}$ & $\begin{array}{l}9.0 \\
9.3 \\
9.6 \\
9.6\end{array}$ & $\begin{array}{l}2.34 \\
2.56 \\
2.33 \\
2.28\end{array}$ & $\begin{array}{l}7.2 \\
7.3 \\
7.5 \\
7.3\end{array}$ \\
\hline 4 & $\begin{array}{c}\text { Fasting } \\
1 \\
2 \\
3\end{array}$ & $\begin{array}{l}3.5 \\
4.4 \\
7.5 \\
5.3\end{array}$ & $\begin{array}{l}2.9 \\
3.1 \\
3.1 \\
3.1\end{array}$ & $\begin{array}{l}0.6 \\
1.3 \\
4.4 \\
2.2\end{array}$ & $\begin{array}{l}8.3 \\
8.5 \\
8.8 \\
8.3\end{array}$ & $\begin{array}{l}2.44 \\
2.44 \\
2.71 \\
2.49\end{array}$ & $\begin{array}{l}5.6 \\
5.7 \\
5.8 \\
5.6\end{array}$ \\
\hline 5 & $\begin{array}{c}\text { Fasting } \\
1 \\
2 \\
3\end{array}$ & $\begin{array}{l}4.7 \\
5.8 \\
7.0 \\
5.8\end{array}$ & $\begin{array}{l}3.5 \\
3.7 \\
4.3 \\
4.3\end{array}$ & $\begin{array}{l}1.2 \\
2.1 \\
2.7 \\
1.5\end{array}$ & $\begin{array}{l}10.3 \\
10.5 \\
10.6 \\
10.6\end{array}$ & $\begin{array}{l}2.25 \\
2.70 \\
2.05 \\
2.20\end{array}$ & $\begin{array}{l}5.9 \\
5.9 \\
6.1 \\
6.1\end{array}$ \\
\hline 6 & $\begin{array}{c}\text { Fasting } \\
1 \\
2 \\
3\end{array}$ & $\begin{array}{l}5.6 \\
7.0 \\
8.1 \\
7.0\end{array}$ & $\begin{array}{l}4.5 \\
5.0 \\
5.0 \\
5.0\end{array}$ & $\begin{array}{l}1.1 \\
2.0 \\
3.1 \\
2.0\end{array}$ & $\begin{array}{r}9.5 \\
10.3 \\
10.3 \\
10.3\end{array}$ & $\begin{array}{l}1.95 \\
2.40 \\
1.95 \\
1.95\end{array}$ & $\begin{array}{l}6.9 \\
6.9 \\
7.0 \\
7.2\end{array}$ \\
\hline 7 & $\begin{array}{c}\text { Fasting } \\
1 \\
2 \\
3\end{array}$ & $\begin{array}{l}4.9 \\
5.7 \\
5.6 \\
5.3\end{array}$ & $\begin{array}{l}4.2 \\
4.4 \\
4.5 \\
4.6\end{array}$ & $\begin{array}{l}0.7 \\
1.3 \\
1.1 \\
0.7\end{array}$ & $\begin{array}{l}10.1 \\
11.0 \\
10.9 \\
10.8\end{array}$ & $\begin{array}{l}2.36 \\
2.42 \\
2.61 \\
2.29\end{array}$ & $\begin{array}{l}7.1 \\
7.3 \\
7.2 \\
7.3\end{array}$ \\
\hline 8 & $\begin{array}{c}\text { Fasting } \\
1 \\
2 \\
3\end{array}$ & $\begin{array}{l}3.9 \\
5.0 \\
5.1 \\
4.6\end{array}$ & $\begin{array}{l}3.4 \\
3.6 \\
3.7 \\
3.5\end{array}$ & $\begin{array}{l}0.5 \\
1.4 \\
1.4 \\
0.9\end{array}$ & $\begin{array}{l}10.2 \\
10.9 \\
10.8 \\
10.8\end{array}$ & $\begin{array}{l}1.84 \\
2.06 \\
2.06 \\
2.03\end{array}$ & $\begin{array}{l}6.5 \\
6.6 \\
6.6 \\
6.5\end{array}$ \\
\hline 9 & $\begin{array}{c}\text { Fasting } \\
1 \\
2 \\
3\end{array}$ & $\begin{array}{l}3.7 \\
4.2 \\
4.7 \\
5.2\end{array}$ & $\begin{array}{l}2.6 \\
2.8 \\
2.9 \\
3.0\end{array}$ & $\begin{array}{l}1.1 \\
1.4 \\
1.8 \\
2.2\end{array}$ & $\begin{array}{r}9.9 \\
10.2 \\
10.2 \\
10.4\end{array}$ & $\begin{array}{l}2.36 \\
2.51 \\
2.36 \\
2.30\end{array}$ & $\begin{array}{l}6.7 \\
6.7 \\
6.8 \\
6.9\end{array}$ \\
\hline 10 & $\begin{array}{c}\text { Fasting } \\
1 \\
2 \\
3\end{array}$ & $\begin{array}{l}4.6 \\
5.0 \\
6.9 \\
6.5\end{array}$ & $\begin{array}{l}3.4 \\
3.4 \\
4.0 \\
3.9\end{array}$ & $\begin{array}{l}1.2 \\
1.6 \\
2.9 \\
2.6\end{array}$ & $\begin{array}{l}10.2 \\
10.2 \\
10.4 \\
10.5\end{array}$ & $\begin{array}{l}2.18 \\
2.30 \\
2.18 \\
2.14\end{array}$ & $\begin{array}{l}6.8 \\
6.7 \\
6.8 \\
6.8\end{array}$ \\
\hline 11 & $\begin{array}{c}\text { Fasting } \\
1 \\
2 \\
3\end{array}$ & $\begin{array}{l}3.7 \\
4.2 \\
4.2 \\
4.4\end{array}$ & $\begin{array}{l}3.5 \\
3.8 \\
3.8 \\
4.1\end{array}$ & $\begin{array}{l}0.2 \\
0.4 \\
0.4 \\
0.3\end{array}$ & $\begin{array}{r}9.8 \\
9.8 \\
10.3 \\
9.4\end{array}$ & $\begin{array}{l}1.60 \\
1.70 \\
1.86 \\
1.43\end{array}$ & $\begin{array}{l}7.2 \\
7.6 \\
7.4 \\
7.4\end{array}$ \\
\hline 12 & $\begin{array}{c}\text { Fasting } \\
1 \\
2 \\
3\end{array}$ & $\begin{array}{l}4.2 \\
5.0 \\
5.5 \\
5.3\end{array}$ & $\begin{array}{l}3.9 \\
4.5 \\
4.8 \\
4.8\end{array}$ & $\begin{array}{l}0.3 \\
0.5 \\
0.7 \\
0.5\end{array}$ & $\begin{array}{l}8.1 \\
8.5 \\
8.0 \\
8.3\end{array}$ & $\begin{array}{l}2.10 \\
2.31 \\
2.14 \\
1.90\end{array}$ & $\begin{array}{l}7.5 \\
7.7 \\
7.4 \\
7.4\end{array}$ \\
\hline
\end{tabular}

* Hospital patients with apparently no impairment of intestinal function. Results are averages of duplicates. for the recovery determinations. The accuracy of the protein method was estimated at approximately 3 per cent by comparing the procedure used with the Kjeldahl procedure on 50 samples, in the routine laboratory. All analyses were done in duplicate and the tables below show the results of the average of these duplicates.

The experiments were performed in the following manner: A fasting sample of blood was drawn and 6 grams (12 pills), of calcium fructose diphosphate were taken by mouth. Thereafter, samples of blood were taken at intervals of one hour for three hours.

Results are shown in 12 cases in Table I (cases 1 through 12). Summary of these results is shown in Tables II and III where the various determinations are averaged for cases 1 through 12 . Table IV shows the results carried out with a calcium fructose diphosphate powder preparation which had been hydrolyzed by nine months' exposure to moisture in the powder and air. On analysis, approximately 80 per cent of the phosphorus was in inorganic form. These results serve as a "blank" for comparison of the absorption of a hexosephosphate with a phosphate preparation which contained the same quantity of calcium and phosphorus, but little organic phosphate.

\section{DISCUSSION}

Examination of Table III shows a rise of approximately 15 per cent in inorganic phosphorus, and a rise of 173 per cent of the non-protein organic phosphorus, over the fasting level. That these results are statistically significant is apparent from Table I where increases are observed in every case without exception. The control table (Table IV) indicates that the total rise in organic phosphorus levels could not be caused by the ingestion of inorganic phosphate. In view of the small amount of organic phosphate normally present in cell-free serum, the 173 per cent rise is somewhat misleading. An estimation of the amount of organic phosphate absorbed is best obtained by examination of the average absolute rise in non-protein organic phosphate. This is listed as $1.40 \mathrm{mg}$. per $100 \mathrm{ml}$. in Table III. Assuming that 20 per cent of the body weight represents total extracellular fluid, the average adult would have 20 per cent $\times 75 \mathrm{Kg}$. $=15$ liters of extracellular fluid. The total non-protein organic phosphorus increase would then be $1.4 \times 10 \times 15 \div 1000=$ 0.210 gram. Since the phosphorus represents only 13 per cent of the calcium fructose diphosphate 
TABLE II

Average values for the 12 cases studied

(Table I, cases 1-12)

\begin{tabular}{|c|c|c|c|c|c|c|c|c|c|}
\hline & \multicolumn{3}{|c|}{ Calcium } & \multicolumn{3}{|c|}{ Total protein } & \multicolumn{3}{|c|}{ Citric acid } \\
\hline & Mg. \% & $\begin{array}{l}\text { Mg. \% rise } \\
\text { over } \\
\text { fasting }\end{array}$ & $\begin{array}{l}\text { \% Rise } \\
\text { over } \\
\text { fasting }\end{array}$ & Mg. \% & $\begin{array}{l}\text { Mg. \% rise } \\
\text { over } \\
\text { fasting }\end{array}$ & $\begin{array}{l}\text { \% Rise } \\
\text { over } \\
\text { fasting }\end{array}$ & Mg. $\%$ & $\begin{array}{l}\text { Mg. \% rise } \\
\text { over } \\
\text { fasting }\end{array}$ & $\begin{array}{l}\text { \% Rise } \\
\text { over } \\
\text { fasting }\end{array}$ \\
\hline $\begin{array}{l}\text { Fasting } \\
1 \text { hr. } \\
2 \text { hrs. } \\
3 \text { hrs. }\end{array}$ & $\begin{array}{r}9.59 \\
9.90 \\
10.01 \\
9.95\end{array}$ & $\begin{array}{l}\overline{0.31} \\
0.42 \\
0.36\end{array}$ & $\begin{array}{l}-3.2 \\
4.4 \\
3.8\end{array}$ & $\begin{array}{l}6.76 \\
6.80 \\
6.80 \\
6.73\end{array}$ & $\begin{array}{l}\overline{0.04} \\
0.04 \\
0.03\end{array}$ & $\begin{array}{l}-\overline{0.6} \\
0.6 \\
0.4\end{array}$ & $\begin{array}{l}2.06 \\
2.28 \\
2.19 \\
2.10\end{array}$ & $\begin{array}{l}\overline{0.22} \\
0.13 \\
0.04\end{array}$ & $\begin{array}{r}\overline{10.7} \\
6.8 \\
1.9\end{array}$ \\
\hline
\end{tabular}

used, this would imply that 1.6 grams of fructose diphosphate is present in the extracellular fluid at the time of the peak rise in nonprotein organic phosphorus as an average for the 12 adults. The one hour, two hour and three hour figures in Table III for organic phosphorus indicate that a continuous process of absorption and metabolism is going on. From this observation and the fact that some fructose diphosphate is probably hydrolyzed by the acid in the stomach, one might infer that a high percentage of the fructose diphosphate which reaches the intestine is rapidly absorbed. The speed of absorption is indicated by the fact that a rise in non-protein organic phosphorus can be demonstrated in one hour and that a peak is reached in two hours. This compares in speed with the absorption of glucose. A more accurate picture would have been obtained if enteric coated pills had been used.

It is of interest that at no time did the inorganic phosphorus levels rise to a point where a hazard of tetany might be encountered. At the peak, the inorganic phosphorus rise was less than one-third that of the rise in organic non-protein phosphorus. This rise in inorganic phosphorus is equivalent to 0.59 gram of calcium fructose di- phosphate. Thus at the peak rise, more than onethird of the substance administered (6 grams) could be accounted for in the extracellular fluid (1.6 grams +0.59 gram $=2.19$ grams), calculated on the rise in total phosphorus.

The ratio of the phosphorus to calcium absorbed should have been $31 / 40$ or approximately $3 / 4$ if the calcium fructose diphosphate molecule had been absorbed directly. Actually the ratio was $1.91 / 0.42$ (see Tables III and IV), or $9 / 2$ approximately. Disproportion between the absorption of calcium and organic phosphorus may be interpreted on the basis that the molecule is not absorbed as a whole, but that in the intestinal tract calcium dissociates, and the fructose diphosphate is absorbed in greater amounts than calcium. This could only be demonstrated if the amount of calcium excreted in the stool were measured. In the present study stool analyses were not done.

The relatively slight increase in calcium concentration (Table II) suggested that a large portion of the calcium may be tightly bound in organic form. However, ashing made no significant difference ( 2 per cent increase) in the calcium content of the same serum at the peak organic phosphorus level. Increase in citrate levels is

TABLE III

Average values for the 12 cases studied

(Table I, cases 1-12)

\begin{tabular}{|c|c|c|c|c|c|c|c|c|c|}
\hline & \multicolumn{3}{|c|}{ Total non-protein phosphorus } & \multicolumn{3}{|c|}{ Inorganic phosphorus } & \multicolumn{3}{|c|}{ Organic non-protein phosphorus } \\
\hline & Mg. \% & $\begin{array}{l}\text { Mg. \% rise } \\
\text { over } \\
\text { fasting }\end{array}$ & $\begin{array}{l}\text { \% Rise } \\
\text { over } \\
\text { fasting }\end{array}$ & Mg. \% & $\begin{array}{c}\text { Mg. \% rise } \\
\text { over } \\
\text { fasting }\end{array}$ & $\begin{array}{l}\text { \% Rise } \\
\text { over } \\
\text { fasting }\end{array}$ & Mg. \% & $\begin{array}{l}\text { Mg. \% rise } \\
\text { over } \\
\text { fasting }\end{array}$ & $\begin{array}{l}\text { \% Rise } \\
\text { over } \\
\text { fasting }\end{array}$ \\
\hline $\begin{array}{l}\text { Fasting } \\
1 \text { hr. } \\
2 \text { hrs. } \\
3 \text { hrs. }\end{array}$ & $\begin{array}{l}4.19 \\
5.17 \\
6.10 \\
5.58\end{array}$ & $\begin{array}{l}\overline{0.98} \\
1.91 \\
1.39\end{array}$ & $\begin{array}{l}\overline{23} \\
46 \\
33\end{array}$ & $\begin{array}{l}3.40 \\
3.66 \\
3.91 \\
3.88\end{array}$ & $\begin{array}{l}\overline{0.26} \\
0.51 \\
0.48\end{array}$ & $\begin{array}{r}\overline{7.65} \\
15.00 \\
14.10\end{array}$ & $\begin{array}{l}0.79 \\
1.51 \\
2.19 \\
1.70\end{array}$ & $\begin{array}{l}\overline{0.72} \\
1.40 \\
0.91\end{array}$ & $\begin{array}{r}\overline{92} \\
173 \\
116\end{array}$ \\
\hline
\end{tabular}


TABLE IV

Change in serum levels after administration of 6 grams of hydrolyzed calcium fructose diphosphate

\begin{tabular}{|c|c|c|c|c|c|c|c|}
\hline \multirow{2}{*}{$\begin{array}{l}\text { Case* } \\
\text { no. }\end{array}$} & \multirow{2}{*}{ Time } & \multicolumn{3}{|c|}{$\begin{array}{l}\text { Non-protein phos- } \\
\text { phorus (me. \%) }\end{array}$} & \multirow{2}{*}{$\begin{array}{l}\text { Cal- } \\
\text { cium }\end{array}$} & \multirow{2}{*}{ Citrate } & \multirow{2}{*}{ Protein } \\
\hline & & Total & $\begin{array}{l}\text { Inor- } \\
\text { ganic }\end{array}$ & Organic & & & \\
\hline 13 & $\begin{array}{c}\text { hrs. } \\
\text { Fasting } \\
1 \\
2 \\
3\end{array}$ & $\begin{array}{l}4.2 \\
4.6 \\
4.6 \\
4.6\end{array}$ & $\begin{array}{l}3.9 \\
4.1 \\
4.1 \\
4.2\end{array}$ & $\begin{array}{l}0.3 \\
0.5 \\
0.5 \\
0.4\end{array}$ & $\begin{array}{c}\text { ms. } \% \\
9.0 \\
9.6 \\
9.5 \\
9.4\end{array}$ & $\begin{array}{c}m g . \% \\
1.90 \\
2.20 \\
2.10 \\
1.90\end{array}$ & $\begin{array}{l}\% \\
6.0 \\
6.0 \\
6.2 \\
6.0\end{array}$ \\
\hline 14 & $\begin{array}{c}\text { Fasting } \\
\mathbf{1} \\
2 \\
3\end{array}$ & $\begin{array}{l}4.4 \\
5.0 \\
5.3 \\
5.5\end{array}$ & $\begin{array}{l}3.8 \\
4.3 \\
4.5 \\
4.8\end{array}$ & $\begin{array}{l}0.6 \\
0.7 \\
0.8 \\
0.7\end{array}$ & $\begin{array}{l}10.0 \\
10.0 \\
10.3 \\
10.1\end{array}$ & $\begin{array}{l}2.20 \\
2.10 \\
2.33 \\
2.25\end{array}$ & $\begin{array}{l}7.4 \\
7.5 \\
7.2 \\
7.2\end{array}$ \\
\hline 15 & $\begin{array}{c}\text { Fasting } \\
1 \\
2 \\
3\end{array}$ & $\begin{array}{l}3.5 \\
3.9 \\
4.3 \\
4.8\end{array}$ & $\begin{array}{l}3.0 \\
3.3 \\
3.5 \\
4.0\end{array}$ & $\begin{array}{l}0.5 \\
0.6 \\
0.8 \\
0.8\end{array}$ & $\begin{array}{l}10.0 \\
10.3 \\
10.5 \\
10.2\end{array}$ & $\begin{array}{l}2.20 \\
2.36 \\
2.33 \\
2.33\end{array}$ & $\begin{array}{l}7.3 \\
7.6 \\
7.6 \\
7.3\end{array}$ \\
\hline 16 & $\begin{array}{c}\text { Fasting } \\
1 \\
2 \\
3\end{array}$ & $\begin{array}{l}8.2 \\
8.2 \\
8.1 \\
8.2\end{array}$ & $\begin{array}{l}7.6 \\
7.4 \\
7.4 \\
7.5\end{array}$ & $\begin{array}{l}0.6 \\
0.8 \\
0.7 \\
0.7\end{array}$ & $\begin{array}{l}8.0 \\
8.7 \\
8.7 \\
8.1\end{array}$ & $\begin{array}{l}2.10 \\
2.54 \\
2.15 \\
1.92\end{array}$ & $\begin{array}{l}\mathbf{5 . 0} \\
\mathbf{5 . 4} \\
\mathbf{5 . 0} \\
\mathbf{5 . 0}\end{array}$ \\
\hline 17 & $\begin{array}{c}\text { Fasting } \\
\mathbf{1} \\
2 \\
3\end{array}$ & $\begin{array}{l}6.2 \\
6.0 \\
6.0 \\
6.2\end{array}$ & $\begin{array}{l}5.5 \\
5.5 \\
5.4 \\
5.4\end{array}$ & $\begin{array}{l}0.7 \\
0.5 \\
0.6 \\
0.8\end{array}$ & $\begin{array}{l}7.7 \\
8.1 \\
7.6 \\
7.6\end{array}$ & $\begin{array}{l}1.92 \\
2.03 \\
2.06 \\
1.96\end{array}$ & $\begin{array}{l}4.7 \\
4.8 \\
4.7 \\
4.7\end{array}$ \\
\hline $\begin{array}{c}\text { Aver- } \\
\text { age }\end{array}$ & $\begin{array}{c}\text { Fasting } \\
1 \\
2 \\
3\end{array}$ & $\begin{array}{l}5.3 \\
5.4 \\
5.6 \\
5.9\end{array}$ & $\begin{array}{l}4.8 \\
4.9 \\
5.0 \\
5.2\end{array}$ & $\begin{array}{l}0.5 \\
0.5 \\
0.6 \\
0.7\end{array}$ & $\begin{array}{l}8.9 \\
9.3 \\
9.3 \\
9.1\end{array}$ & $\begin{array}{l}2.06 \\
2.25 \\
2.20 \\
2.06\end{array}$ & $\begin{array}{l}6.1 \\
6.2 \\
6.1 \\
6.0\end{array}$ \\
\hline
\end{tabular}

* Hospital patients with apparently no impairment of intestinal function. Results are averages of duplicates.

probably associated with the rise in calcium levels (15). Protein changes were not considered significant.

Certain pathological conditions exist such as hyperparathyroidism (16), and low phosphorus rickets (17-19), where the phosphate levels of the blood cannot be maintained even when inorganic phosphate is administered. In lead poisoning, the administration of phosphorus has been suggested in order to alleviate symptoms by removal of lead from the plasma (20-22). This technique has been hampered by the danger associated with injections of inorganic phosphorus. The authors intend to investigate the possibility that hexosephosphates may find application in these cases.

The properties ascribed to calcium fructose diphosphate in this report are apparently not limited to fructose diphosphate since calcium glycerol phosphate, when tested in one case, produced similar results. It is the intention of the authors to extend this study to other phosphate esters such as glucose 6 phosphate, and glucose 1 phosphate.

\section{SUMMARY}

1. The effect of 6 grams of calcium fructose diphosphate administered orally on the calcium, protein, citric acid, inorganic phosphorus and non-protein organic phosphorus levels of the serum was studied in 12 adults.

2. The results show an average increase in the calcium concentration of 4.4 per cent. Citric acid rose 10.7 per cent over the fasting levels. Inorganic phosphorus levels rose an average of 15 per cent. The greatest change was noted in the case of non-protein organic phosphorus which was of the order of 173 per cent increase.

3. Six grams of hydrolyzed calcium fructose diphosphate given orally did not cause a similar rise in non-protein organic phosphate in five cases.

\section{REFERENCES}

1. Cori, C. F., and Cori, G. T., The fate of sugar in the animal body. III. The rate of glycogen formation in the liver of normal and insulinized rats during absorption of glucose, fructose, and galactose. J. Biol. Chem., 1926, 70, 577.

2. Feyder, S., and Pierce, H. B., Rates of absorption and glycogenesis from various sugars. J. Nutrition, 1935, 9, 435.

3. Donhoffer, S., Uber die elektive Resorption der Zucker. Arch. f. Exper. Path. u. Pharmakol., 1935, 177, 689.

4. Cajori, F. A., and Karr, W. G., Absorption of glucose and galactose from the dog's intestine. Am. J. M. Sc., 1935, 189, 880.

5. Verzár, F., and Laszt, L., Die Resorption aus dem Darm von isotonischen Lösungen von Glucose und Sorbose, verglichen mit der von Natriumsulfat. Biochem. Ztschr., 1935, 276, 28.

6. Laszt, L., Die Resorption von Glucose und Xylose bei verschiedener $\mathrm{H}$-Konzentration. Biochem. Ztschr., 1935, 276, 40.

7. Laszt, L., and Süllmann, H., Nachweis der Bildung von Phosphorsäure-estern in der Darm-Schleimhaut bei der Resorption von Zuckern und Glycerin. Biochem. Ztschr., 1935, 278, 401.

8. Garrer, A. A., Groen, J., and Hallen, L., Absorption of glucose from the human rectum. Acta med. Scandinav., 1941, 107, 1.

9. Beck, L. V., Organic phosphate and "fructose" in rat intestinal mucosa as affected by glucose and phlorhizin. J. Biol. Chem., 1942, 143, 403.

10. Mathieu, F., Die Resorption von Hexose-di und -mono- 
phosphorsäure im Vergleich zu anderen Hexosen. Biochem. Ztschr., 1935, 276, 49.

11. Sobel, A. E., and Sobel, B. A., Microestimation of calcium in serum. J. Biol. Chem., 1939, 129, 721.

12. Hawk, P. B., Oser, B. L., and Summerson, W. H., Practical Physiological Chemistry. Blakiston, Philadelphia, 1947, 12th edition.

13. Kingsley, G. R., The direct biuret method for the determination of serum proteins as applied to photoelectric and visual colorimetry. J. Lab. \& Clin. Med., 1942, 27, 840.

14. Natelson, S., Pincus, J. B., and Lugovoy, J. K., Microestimation of citric acid. A new colorimetric reaction for pentabromoacetone. J. Biol. Chem., 1948, 175, 745.

15. Wexler, I. B., Pincus, J. B., Natelson, S., and Lugovoy, J. K., III. The fate of citrate in erythroblastotic infants treated with exchange transfusion. J. Clin. Invest., 1949, 28, 474.

16. Albright, F., and Reifenstein, E. C., Jr., The Parathyroid Glands and Metabolic Bone Disease; Selected Studies. Williams \& Wilkins, Baltimore, 1948, pp. 58-62.
17. Fanconi, G., Der frühinfantile nephrotisch-glykosurische Zwergwuchs mit hypophosphatämischer Rachitis. Jahrb. f. Kinderh., 1936, 147, 299.

18. Debré, R., Marie, J., Cleret, F., and Messimy, Rachitisme tardif coexistant avec une néphrite chronique et une glycosurie. Soc. de pédiat. de Paris, 1934, 32, 305; also Arch. de med. d. enf., 1934, 37, 597.

19. Gittleman, I. F., and Pincus, J. B., Rickets associated with dwarfism, glycosuria, ketonuria, and albuminuria. Am. J. Dis. Child., 1940, 60, 1351.

20. Shelling, D. H., Effect of dietary calcium and phosphorus on the toxicity of lead in the rat; rationale of phosphate therapy. Proc. Soc. Exper. Biol. \& Med., 1932, 30, 248.

21. Shelling, D. H., and Hopper, K. B., Calcium and phosphorus studies. XII. Six years' clinical experience with viosterol in the prevention and treatment of rickets, tetany and allied diseases. Bull. Johns Hopkins Hosp., 1936, 58, 137.

22. Gray, I., and Greenfield, I., Lead poisoning; newer concepts in the treatment of lead poisoning. New York State J. Med., 1938, 38, 1313. 